\title{
Rules and Routines in Covid-19: How Are The Applications In Physical Education
} Learning In School?

\author{
Panuwun Joko Nurcahyo ${ }^{1}$, Rifqi Festiawan ${ }^{2 *}$, Didik Rilastiyo Budi ${ }^{3}$, Arfin Deri Listiandi ${ }^{4}$ \\ Ngadiman $^{5}$, Kusnandar ${ }^{6}$, Muhamad Syafei ${ }^{7}$ \\ 1,2,3,4,5,6 Physical Education Study Program, Faculty of Health Science, Jenderal Soedirman \\ University, Central Java, Indonesia \\ * Correspondence author. E-mail: rifqi.festiawan@unsoed.ac.id
}

Received: 11 October 2020; Revised: 16 October 2020; Accepted: 22 October 2020

https://doi.org/10.24036/MensSana.050220.05

\begin{abstract}
This study aims to determine the application of the rules (rules) and routines (routines) in the learning process of Physical Education in SMP Negeri throughout Banyumas Regency. This research is quantitative descriptive research. The research method used was a survey method. The subjects in this study were physical education teachers in Banyumas Regency, totaling 36 schools. The sampling technique uses a total sampling technique. The research instrument used in the form of a questionnaire application of rules (rules) with a validity coefficient of 0.925 and a reliability coefficient of 0.991, as well as a routine questionnaire (routines) with a validity coefficient of 0.925 and a reliability coefficient of 0.987. Data analysis techniques using quantitative descriptive analysis presented in the form of a percentage. The results showed that: (1) The application of the rules in Physical Education learning in state junior high schools in Banyumas Regency was in the category of "very less" by 0\% (0 teachers), "less" by 0\% (0 teachers), "Enough" at 30.56\% (11 teachers), "good" at $69.44 \%$ (25 teachers), and "very good" at 0.00\% (0 teachers). (2) Implementation of routines in Physical Education learning in state junior high schools in Banyumas Regency is in the category of "very less" by 0\% (0 teachers), "less" by 0\% (0 teachers), "enough" by 69, 44\% (25 teachers), "good" by $27.78 \%$ (10 teachers), and "very good" by $2.78 \%$ (1 teacher). With these results, it can be concluded that the application of rules and routines in SMPs throughout Banyumas Regency is in the sufficient category.
\end{abstract}

\section{Keywords: Rules, Routines, Physical Education, Learning}

\section{INTRODUCTION}

One of the subjects taught at school is

Physical Education. Physical Education learning activities that need attention not only when the activity takes place but from the beginning to the end of the activity all must be considered (Wicaksono et al., 2020). The rules in the Physical Education class, starting from the students coming to the Physical Education class, continue with the students changing clothes, until the students leave the class (Raiola, 2011).
Therefore, a Physical Education teacher must be able to arrange the class in such a way that there are no problems that can interfere with the learning process Dyson (2014). Usually, the problems that often occur in Physical Education classes are related to student behavior problems, which tend to hamper learning activities.

To discipline the class the problem faced by teachers, both beginners and experienced, is classroom management (Jessica, 2018). The challenge as a Physical Education teacher is to create a learning environment that supports the 
smooth implementation of the learning process so that students can achieve their learning goals (Tsuda el al., 2019). Success in the teaching and learning process starts with good classroom management. Initial treatment in class management refers to proactive, not reactive actions (McEntyre et al., 2020). So the application of rules and routines must get attention from the Physical Education teacher (Rink, 2014).

A successful managerial system begins with the development and formation of rules and routines in the classroom (Alcock, 2007). In planning rules and routines, the teacher must consider the needs of students and the physical environment of the class (Reynaud, 2005). Some literature states that it is very important for teachers to create an appropriate learning environment on the first day at the beginning of the new school year (Lazaric, 2000).

Why should it be initiated, because if in the middle of the semester there are things related to improper behavior while a teacher forgets or even has no clear rules then as a teacher will have difficulty controlling it? If the rules have been explained from the beginning then everything will go well (O'Sullivan \& Dyson, 2016).

Rules refer to general expectations for specific behavior settings (Livingstone et al., 2003). We identify appropriate and inappropriate behavior and situations in certain behaviors are acceptable or unacceptable. Routines are procedures that are in class to be followed in daily activities.

Specifically, routines refer to specific procedures for doing assignments in class (Williams, 2001). The teacher must establish a routine with continuous frequency as a task so that more time can be dedicated to a substantial part of the lesson. If the teacher does not have rules and routines then time will be wasted because time is only to remind students related to attitude (Behavior) (Weichbrodt \& Grote, 2010).

Based on observations on 10 October-9 November 2018, it was found that the teacher still prioritizes the technical approach and uses the drill model, that is, students practice continuously and perform assignments given by the teacher, besides that the student's behavior when participating in learning a big ball game like soccer, volleyball, and soccer less enthusiastic and less serious. The teacher is limited to delivering the material and students accept what is conveyed by the teacher. Other problems such as teachers rarely use instructional media in the form of pictures and videos, so sometimes students find it difficult to understand the material (Ensign et al., 2018).

Other problems when students will play soccer are still many students who do not understand the basic techniques that will be used when playing soccer such as dribbling, passing and so far students have been playing soccer just from playing (Festiawan et al., 2019).

In addition to lack of understanding, the facilities and infrastructure are also not yet supportive, such as the lack of available soccer, the untreated ring, and not in its position, so students have difficulty inserting the ball in one of the rings, the field lines fade so students do not know the violations committed if not supervised directly by the teacher who teaches Metzler (2014).

Students who are less active in the Physical Education learning process, caused by one-way or monotonous learning, lack of learning media, inadequate school facilities, and infrastructure (Kyriakides, 2018). This can result in students lacking understanding of the material being studied and lacking enthusiasm in learning, so the learning objectives will not be achieved properly.

That is what causes the low learning outcomes of students, so many students who have not succeeded in achieving the Minimum Mastery Criteria. This can be seen from the end of the learning activity that is when summarizing the learning material, some students have forgotten the material that has just been obtained. Learning conditions of students like this must continue to be sought to be improved.

The implementation of learning in several junior high schools in Banyumas Regency, 
teachers do not empower the learning environment, the learning environment of students, in schools both in the classroom and in the classroom environment are less structured in such a way that supports the learning process in the classroom, and the teachers in teaching use approaches that are being developed but not followed by the use of methods that support the use of the approach. Based on these problems, researchers are interested in researching with the title "Identification of the Application of Rules and Routines in Physical Education Learning in Public Middle Schools in Banyumas Regency".

\section{METHOD}

\section{Types of Research}

This type of research is quantitative descriptive research. (Sugiyono, 2016) states that "descriptive research is used to describe or describe data that has been collected as it is". The method used is a survey and data collection techniques using a questionnaire. This study aims to identify the application of rules and routines in the study of Physical Education in state junior high schools in Banyumas.

\section{Time and Place of Research}

This research was conducted in 36 public schools in Banyumas Regency. When the study was conducted in July 2019.

\section{Research Targets / Subjects}

The population in this study were all Physical Education teachers in Banyumas Regency from 36 schools. (Arikunto, 2010) states that "the sample is partial or representative investigated. The sampling technique is a total sampling of 36 teachers.

\section{Data, Instruments, and Data Collection Techniques}

The instrument used in this study was a closed questionnaire. The scale used is the Gutman scale, which is Yes (given a value of 1) and No (given a value of 0 ). The lattice of the instrument application of the Rules and Routines in Learning Physical Education in the Public
Middle Schools in Banyumas Regency is presented in the following table:

Table 1. Regulatory Instrument Lattice Rules (Rules) in Physical Education Learning

\begin{tabular}{|c|c|c|}
\hline & Indikator & No Butir \\
\hline \multirow[t]{14}{*}{ Peraturan } & $\begin{array}{l}\text { a. Peraturan harus mengembangkan kooperatif/kerjasama antar } \\
\text { siswa (Rules should be develop cooperatively with students) }\end{array}$ & 1,2 \\
\hline & \begin{tabular}{|l|l} 
b. Peraturan harus dikomunikasikan awal dalam bahasa yang \\
sesuai dengan usianya (Rule should be communicated in \\
beginning of school year with language that is age appropriate)
\end{tabular} & $3,4,5$ \\
\hline & $\begin{array}{l}\text { c. Peraturan harus sedikit (4-7), sehingga siswa akan } \\
\text { mengingatnya. (Rules should be few (four to seven) so student } \\
\text { will remember them }\end{array}$ & $6,7,8$ \\
\hline & $\begin{array}{l}\text { d. Dimulai dengan peraturan secara positif dan memberikan contoh } \\
\text { dari keduannya baik positif dan negatif (State rules positively } \\
\text { and provide both positive and negative examples) }\end{array}$ & $9,10,11,12$ \\
\hline & $\begin{array}{l}\text { e. Peraturan harus konsisten dengan peraturan sekolah (Rules must } \\
\text { be consistent with school rules) }\end{array}$ & 13,14 \\
\hline & \begin{tabular}{|l} 
f. Mengembangkan konsekuensi dan secara jelas mengidentifikasi \\
hubungan mereka dengan pelanggaran peraturan (Develop the \\
consequence and clearly identify their relationship to rules \\
violations)
\end{tabular} & 15,16 \\
\hline & $\begin{array}{l}\text { g. Memperkuat peraturan secara konsisten dan adil (Reinforce the } \\
\text { rules consistently and fairly) }\end{array}$ & 17,18 \\
\hline & $\begin{array}{l}\text { h. Make sure the students understand the rules (Pastikan siswa } \\
\text { memahami peraturan). }\end{array}$ & $19,20,21$ \\
\hline & $\begin{array}{ll}\text { i. } & \text { Keselamatan (Safety) } \\
\end{array}$ & $22,23,24,25$ \\
\hline & $\begin{array}{l}\text { j. Menghormati dan sopan dengan orang lain (Respect and be } \\
\text { polite with others) }\end{array}$ & $26,27,28$ \\
\hline & $\begin{array}{l}\text { k. Menghormati ligkungan pembelajaran (Respect for the learning } \\
\text { environment) }\end{array}$ & 29,30 \\
\hline & 1. Mendukung pembelajaran lainnya (Support for other learning) & $31,32,33$ \\
\hline & m. Usaha Keras (Trying hard) & 34,35 \\
\hline & n. Publikasi peraturan & $36,37,38,39,40$ \\
\hline & Jumlah & 40 \\
\hline
\end{tabular}

Table 2. Routes of Instrument Variables Lines

(Routines) in Physical Education Learning

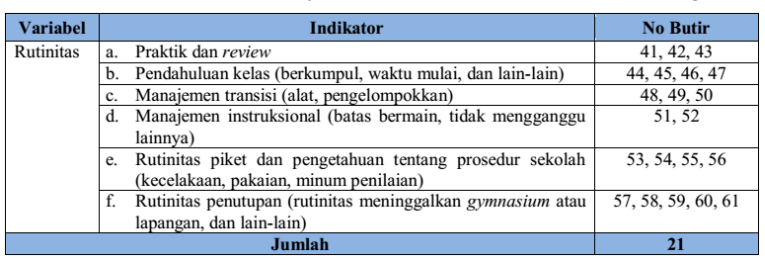

Data collection is a process of procuring data for research purposes. Data collection techniques in this research are by giving questionnaires to respondents who are the subjects in the study. The mechanism is as follows:

1. Researchers are looking for Physical Education teacher data in state junior high schools in Banyumas Regency.

2. The researcher determined the number of Physical Education teachers in the State Junior High Schools in Banyumas Regency who were the subjects of the study.

3. The researcher distributes the test to respondents.

4. Next, the researchers collected the results and transcribed the results of the test completion. 
5. After obtaining research data the researchers draw conclusions and suggestions.

\section{Data Analysis Technique}

The data analysis technique in this study used descriptive percentage data analysis techniques.

$$
\mathrm{P}=\frac{F}{N} X 100 \%
$$

Determine the interval using the formula from Arikunto (2010: 207) in table 3 as follows:

Table 3. Assessment Norms

\begin{tabular}{cc}
\hline Interval & Category \\
\hline $81 \%-100 \%$ & Very good \\
$61 \%-80 \%$ & Good \\
$41 \%-60 \%$ & Enough \\
$21 \%-40 \%$ & Less \\
$0 \%-20 \%$ & Very less \\
\hline
\end{tabular}

(Source: Arikunto, 2010: 207)

\section{RESULTS AND DISCUSSION Research Result}

Descriptive statistical data of research results on the application of rules and routines in the study of Physical Education in the Public Middle Schools in Banyumas Regency obtained the lowest score (minimum) 38.10, highest score (maximum) 85.71, mean (mean) 60.78, median (median) 60.95, frequently occurring values (mode) 60.78, standard deviation (SD) 9.87 .

Table 4. Descriptive Statistical Data Of Research

\begin{tabular}{llllll}
$\begin{array}{l}\text { Minim } \\
\text { um }\end{array}$ & $\begin{array}{l}\text { Maxim } \\
\text { um }\end{array}$ & Mean & $\begin{array}{l}\text { Medi } \\
\text { an }\end{array}$ & $\begin{array}{l}\text { Mo } \\
\text { de }\end{array}$ & SD \\
\hline 38,1 & 85,71 & 60,78 & 60,9 & 60, & 9,8 \\
& & & 5 & 78 & 7
\end{tabular}

The application of rules and routines in Physical Education learning

The application of rules and routines in Physical Education learning in Banyumas Regency Junior High Schools can be presented in table 5 as follows:
Table 5. Application Of Rules And Routines In Physical Education Learning Results

\begin{tabular}{|l|l|l|l|}
\hline No & Category & Jumlah & Presentase \\
\hline 1 & Very good & 1 & $1,39 \%$ \\
\hline 2 & Good & 35 & $48.61 \%$ \\
\hline 3 & Enough & 35 & $48.61 \%$ \\
\hline 4 & Less & 1 & $1.39 \%$ \\
\hline 5 & Very less & 0 & $0 \%$ \\
\hline
\end{tabular}

Based on Table 5 above shows that the application of rules and routines in Physical Education learning in the Public Middle Schools in Banyumas Regency is in the category of "very less" by $0 \%$ (0 teachers), "less" by $1.39 \%$ (1 teacher), "enough" 48.61\% (35 teachers), "good" $48.61 \%$ (35 teachers), and "very good" 1.39\% (1 teacher). Based on the average value, which is 60.78 , the application of rules and routines in the study of Physical Education in SMP Negeri in the Banyumas Regency is in the "sufficient" category. An overview of the results of the above data can be seen in Figure 1 below.

The Application of Rules and Routines In Physical Education Learning

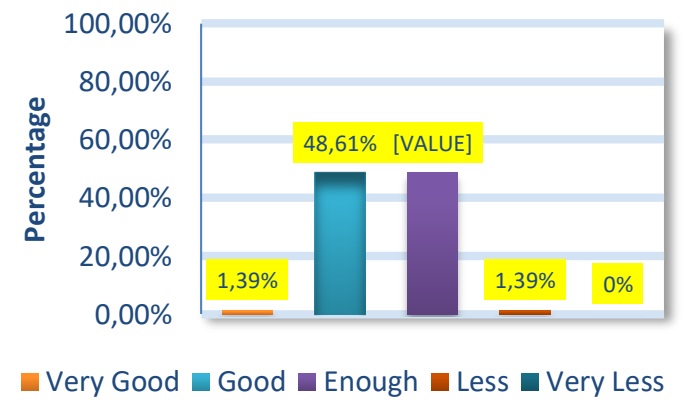

Figure 1. Bar chart of the Application of Rules and Routines in Physical Education Learning in Public Middle Schools in Banyumas Regency

\section{Application of Rules in Learning Physical Education}

The application of the rules in the learning of Physical Education in SMP Negeri in Banyumas Regency can be presented in Table 6 below:

Table 6. Application of Rules in Learning Physical Education results 
Volume 5, Nomor 2, Tahun 2020: 106-114

\begin{tabular}{llll}
\hline No & Category & Jumlah & Presents \\
\hline 1 & Very good & 0 & $0 \%$ \\
2 & Good & 25 & $69,44 \%$ \\
3 & Enough & 11 & $30,56 \%$ \\
4 & Less & 0 & $0 \%$ \\
5 & Very less & 0 & $0 \%$ \\
\hline \multicolumn{3}{c}{ Based on Table 6 above } & shows that the
\end{tabular}

application of rules in learning Physical Education in State Junior High Schools in Banyumas Regency is in the category of "very less" by 0\% (0 teachers), "less" by $0 \%$ (0 teachers), " sufficient "by 50.00\% (18 teachers)," good "by $50.00 \%$ (18 teachers), and" very good "by $0.00 \%$ ( 0 teachers). An overview of the results of the above data can be seen in Figure 2 below.

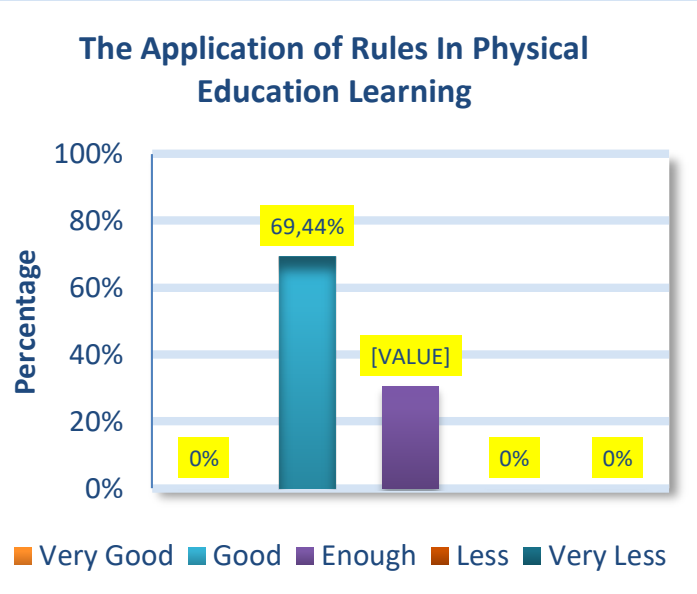

Figure 2. Bar Diagram of Application of Rules in Physical Education Learning

\section{Application of Routines in Physical Education Learning}

The application of routines in the learning of Physical Education in SMP Negeri in Banyumas Regency in Figure 3 follows:

Table 7. Application of Routines in Learning Physical Education Results

\begin{tabular}{llll}
\hline No & Category & Jumlah & Presents \\
\hline 1 & Very good & 1 & $2,78 \%$ \\
2 & Good & 10 & $27,78 \%$ \\
3 & Enough & 25 & $69,44 \%$ \\
4 & Less & 0 & $0 \%$ \\
5 & Very less & 0 & $0 \%$
\end{tabular}

Based on Table 7 above shows that the learning in SMP Negeri in Banyumas Regency is in the category of "very less" by $0 \%$ ( 0 teachers), "less" by $0 \%$ (0 teachers), "Sufficient" by 69.44\% (25 teachers), "good" by $27.78 \%$ (10 teachers), and "very good" by $2.78 \%$ (1 teacher). An overview of the results of the above data can be seen in Figure 3 below.

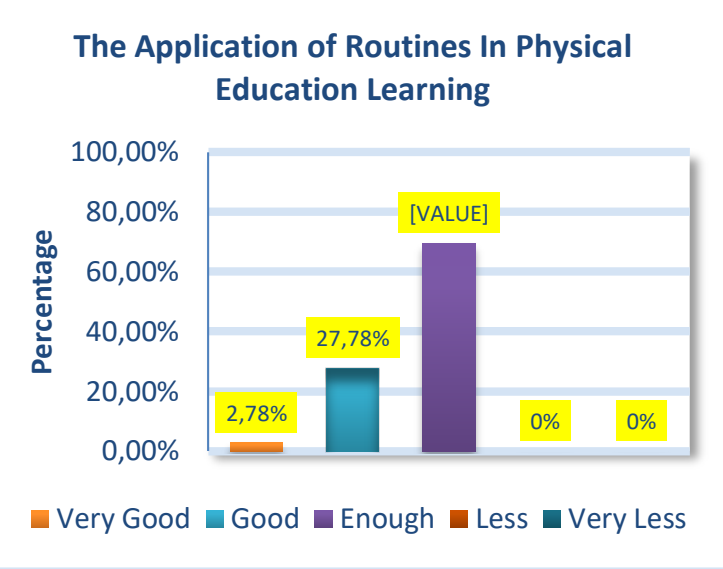

Figure 3. Bar Diagram Implementation of Routines (Routines) in Physical Education Learning

\section{Discussion}

This study aims to determine the application of the rules (rules) and routines (routines) in learning Physical Education in SMP Negeri Banyumas Regency. Based on the results of the study showed that the application of the rules (rules) and routines (routines) in learning Physical Education in SMP Negeri in Banyumas Regency in the category enough.

Learning activities are designed to provide learning experiences that involve mental and physical processes through interactions between students, students and teachers, the environment, and other learning resources to achieve basic competency goals.

Based on the results of data analysis can be known that: 1) The application of rules and routines in Physical Education learning in Banyumas Regency Junior High Schools is in the category of "very poor" by $0 \%$ (0 teachers), "less" by $1.39 \%$ (1 teacher), " sufficient "by 48.61\% (35 teachers)," good "by 48.61\% (35 teachers), and" very good "by $1.39 \%$ (1 teacher). Based on the average value, which is 60.78 , the 
application of rules and routines in the study of Physical Education in SMP Negeri in the Banyumas Regency is in the "sufficient" category. 2)

The application of the rules in the learning of Physical Education in state junior high schools in Banyumas Regency is in the category of "very less" by $0 \%$ ( 0 teachers), "less" by $0 \%$ ( 0 teachers), "enough" by $50.00 \%$ (18 teachers), "good" $50.50 \%$ (18 teachers), and "very good" $0.00 \%$ (0 teachers).

Based on the average value, which is 61.11, the application of the rules (rules) in learning Physical Education in SMP Negeri in the Banyumas Regency is in the "good" category. 3) The application of routines in Physical Education learning in state junior high schools in Banyumas Regency is in the category of "very less" by $0 \%$ ( 0 teachers), "less" by $2.78 \%$ (1 teacher), "enough" by 47, 22\% (17 teachers), "good" by $47.22 \%$ (17 teachers), and "very good" by $2.78 \%$ ( 1 teacher).

Djamarah \& Zain (2010) states the implementation of learning is an activity that has an educational value that colors the interactions that occur between teachers and students. Educative interaction value because the implementation of learning carried out is directed to achieve certain goals that have been formulated before the implementation of learning begins. Broadly speaking, the management of this learning process can be divided into three categories, namely routine management, core management of the learning process, and environmental management and learning materials (Maksum, 2012).

The learning experience will later be outlined in the form of implementation of learning created by the teacher according to the learning plan that has been made with a varied learning approach and is student-centered. According to regulations made by Permendikbud No. 22 of 2016 related to the standard process that is the implementation of learning is the application of the learning implementation plan which includes preliminary activities.
In teaching and learning interactions, teachers and students must be active. Active in the sense of attitude, mentality, and deeds. To create effective teaching and learning interactions, at least the teacher must master and practice a variety of basic teaching skills.

Saud (2011) states the teacher's skills in the teaching and learning process, among others: the skills of opening and closing lessons, the skills of explaining, the skills of asking questions, the skills of reinforcement, the skills of using media learning, the skills of guiding small group discussions, the skills of managing classes, the skills of holding variations and individual and small group teaching skills. In addition to creating positive interactions in the class that is not less important is to build good communication.

Physical Education is one of the subjects in primary schools, activities in Physical Education need to be given attention not only when learning takes place but must be considered from the beginning to the end of learning. During the learning process, teachers can make regulations so that learning runs smoothly.

Rules in Physical Education can be started from students coming to class, followed by students changing clothes, until students leave class. Therefore, a physical education teacher must be able to arrange the class in such a way that there are no problems that can interfere with the learning process (Festiawan et.al, 2020).

The results of the research on the application of rules and routines in the study of Physical Education in SMP Negeri in Banyumas Regency are explained as follows: Based on these results indicate the implementation of the rules (rules) and routines (routines) in learning Physical Education that has been done so far is good.

Both categories indicated that during this time Physical Education learning had not fully applied the rules and routines in Physical Education learning (Festiawan, 2020). This is because the consistency of the learner is needed, the teacher's role as a facilitator can implement the rules and routines. For the implementation of 
rules and routines in Physical Education learning to be carried out properly, it should be implemented in the habit of learning every day, therefore rules and routines must be enforced properly.

Rules help children learn the behaviors needed to work together with others. Rules will make children learn discipline. Rules are learned through written rules and examples continuously so that they get an appropriate and appropriate response to a rule. For regulations to be more effective, they must be clear and enforce fairly and consistently.

Rules help children learn the behaviors needed to work together with others. Rules will make children learn discipline. Rules learned through examples will continuously get an appropriate and appropriate response to a rule. For rules to be more effective, rules must be clear and enforced fairly and consistently (Rink, 2006)

The results of the application of a good routine show that so far the existing regulations have not been fully applied routinely in Physical Education learning. In this case routines or procedures usually refer to specific activities and they are usually shown to complete tasks rather than prohibit behavior.

In connection with the existing regulations that so far the Physical Education teacher has always given sanctions to students who commit improper behavior or violate the rules in Physical Education. Weaknesses of these unwritten rules make sometimes the routine of obeying the rules of martial arts is done well by all students (Festiawan, 2015).

The routine needs to be conveyed specifically as one of the teaching content. Teaching routine means that the teacher must use explanations, demonstrations, practice with feedback, and all other elements related to learning. In other words, the key to effective routine teaching is no different from the key to teaching sports skills. Graham et al., (2001) state that routines are procedures for completing tasks or special tasks in class "routines are different from the rules so routines usually refer to special activities and they are usually intended to complete tasks rather than prohibit behavior ".

\section{CONCLUSION}

Based on the results of data analysis and discussion, conclusions can be drawn that the application of routines in the learning of Physical Education in the State Junior High Schools in Banyumas Regency is in the "enough" category with an average value, which is 60.45 .

\section{CITATIONS AND REFERENCES}

Alcock, S (2007) Playing with rules around routines: children making mealtimes meaningful and enjoyable, Early Years, 27:3, 281-

293, DOI: $\underline{10.1080 / 09575140701594426}$.

Djamarah, S.B \& Zain, A. (2010). Strategi belajar mengajar. Jakarta: Rineka Cipta.

Dyson, B. (2014). Quality Physical Education: A Commentary on Effective Physical Education Teaching, Research Quarterly for Exercise and Sport, 85:2, 144152, DOI: $10.1080 / 02701367.2014 .904155$

Emi Tsuda, James Wyant, Sean M. Bulger, Eloise Elliott, Andrea R. Taliaferro, Charlene Burgeson, Howell Wechsler. (2019) Recommendations for Developing and Implementing State-level Physical Education Accountability Systems in Student Learning. Journal of Physical Education, Recreation \& Dance 90:9, pages $9-15$.

Ermis

Tsangaridou, Charalambos

Kyriakides, Niki

Charalambous, Leonidas, Kyriakides. (2018) Integrating generic and contentspecific teaching practices in exploring teaching quality in primary physical education. European Physical Education Review 24:4, 418-448.

Festiawan, R., Nurcahyo, P. J., \& Pamungkas, H. J. (2019). Pengaruh Latihan Small Sided Games Terhadap Kemampuan Long Pass pada Peserta Ekstrakurikuler Sepakbola. Media Ilmu Keolahragaan Indonesia, 9(1), 
Rules and Routines in Covid-19: How Are The Applications In Physical Education Learning In School? Panuwun Joko Nurcahyo ${ }^{1}$, Rifqi Festiawan ${ }^{2^{*}}$, Didik Rilastiyo Budi ${ }^{3}$, Arfin Deri Listiandi ${ }^{4}$ Ngadiman $^{5}$, Kusnandar ${ }^{6}$, Muhamad Syafei ${ }^{7}$

18-22.

https://doi.org/https://doi.org/10.15294/mik i.v9i1.20666

Festiawan, R., Ngadiman, N., Kusuma, I. J., Nurcahyo, P. J., \& Kusnandar, K. (2019). Pengembangan Model Pembelajaran Pendidikan Jasmani Berbasis Games, Education, and Visualisation (GEV) Untuk Meningkatkan Pengetahuan Kesehatan Reproduksi Olahraga, 4(2), 13-24.

Festiawan, R. (2020). Belajar Dan Pendekatan Pembelajaran. Universitas Jenderal Soedirman.

Festiawan, R. (2015). Pedagogi Olahraga (Sport Pedagogy). Universitas Negeri Yogyakarta.

Jessica, R. (2018). The 21st-century classroom: Technology as a transformative tool in educational routines. Thesis. McMaster University.

Julene Ensign, Amelia Mays Woods, Pamela Hodges Kulinna, Gabriella McLoughlin. (2018) The teaching performance of firstyear physical educators. Physical Education \& Sport Pedagogy 23:6, 592608.

Judith Rink. (2014) Teacher Effectiveness in Physical Education, Consensus?. Research Quarterly for Exercise and Sport 85:3, 282286.

Kelsey McEntyre, Matthew D. CurtnerSmith, K. Andrew R. Richards. (2020) Patterns of Preservice Teacher-Student Negotiation Within the Teaching Personal and Social Responsibility Model. Journal of Teaching in Physical Education 39:2, 264-273.

K. Andrew, R. Richards, Lynn D. Housner, Thomas J. Templin. (2018) Addressing Physical Education Teacher Socialization Through Standardsbased Reform of Physical Education Teacher Education. Quest 70:3, 334-353.

Lazaric, N. (2000). The role of routines, rules and habits in collective learning: Some
epistemological
and
ontological
considerations. European Journal of
Economic and Social Systems, 14(2), 157- 171. https://doi.org/10.1051/ejess:2000115

Locke, L. (1977) Research on Teaching Physical Education: New Hope for a Dismal Science, Quest, 28:1, 216, DOI: $\underline{10.1080 / 00336297.1977 .1051989}$ $\underline{5}$

Livingstone, M. B. E., Robson, P. J., Wallace, J. M. W., \& McKinley, M. C. (2003). How active are we? Levels of routine physical activity in children and adults. Proceedings of the Nutrition Society, 62(3), 681-701. https://doi.org/10.1079/pns2003291

Maksum, A. (2012). Metodologi penelitian dalam olahraga. Surabaya: Unesa University Press.

Matthew D. Curtner-Smith, John R. Todorovich, Simon A. Lacon \& lain G. Kerr (1999) Teachers' Rules, Routines, and Expectations Prior to and Following the Implementation of the National Curriculum for Physical Education, European Journal of Physical Education, 4:1, 1730, DOI: $\underline{10.1080 / 1740898990040102}$

O’Sullivan, M., \& Dyson, B. (2016). Rules, Routines, and Expectations of 11 High School Physical Education Teachers. Journal of Teaching in Physical Education, 13(4), 361-374. https://doi.org/10.1123/jtpe.13.4.361

Pope, C, C. (2014) Seeking connection and coherence in sport pedagogy: minding gaps and contemplating a core, Sport, Education and Society, 19:7, 959. 965, DOI: $10.1080 / 13573322.2014 .904787$

Raiola, G. (2011). A study on Italian primary school rules: neurophysiological and didatics aspects in phisical education and sport. Journal of Physical Education and Sport, 11(2), 43-48.

Reynaud, B. (2005). The void at the heart of rules: Routines in the context of rulefollowing. The case of the Paris Metro Workshop. Industrial and Corporate 
Volume 5, Nomor 2, Tahun 2020: 106-114

Change, 14(5), 847-871.

https://doi.org/10.1093/icc/dth073

Rink, Judith E. (2006). Teaching physical education for learning. McGraw Hill : New York.

Saud, U.S. (2011). Pengembangan Profesi Guru. Bandung: Alfabeta.

Weichbrodt, J., \& Grote, G. (2010). Rules and Routines in Organizations: A Review and Integration. Fourth International Conference on Organizational Routines, 2, 36.

Wibowo, A. (2013). Manajemen pendidikan karakter di sekolah. Yogyakarta: Pustaka Pelajar.

Wicaksono, P. N., Kusuma, I. J., Festiawan, R., \& Widanita, N. (2020). Evaluasi penerapan pendekatan saintifik pada pembelajaran pendidikan jasmani materi teknik dasar passing sepak bola. Jurnal Pendidikan Jasmani Indonesia, 16(1), 41-54. https://doi.org/https://doi.org/10.21831/jpji. v16i1.29774

Williams, P. (2001). Preschool Routines, Peer Learning and Participation. Scandinavian Journal of Educational Research, 45(4), 317-339.

https://doi.org/10.1080/00313830127210 